\title{
Uresničevanje ciljev Lizbonske strategije na regionalni ravni EU in Slovenija
}

UDK: 338.1:061.1EU(045)

\author{
Aleksander Aristovnik \\ Univerza v Ljubljani, Fakulteta za upravo \\ aleksander.aristovnik@fu.uni-lj.si \\ Andrej Pungartnik \\ University of Ljubljana, Faculty of Economics \\ endrej.pungartnik@ef.uni-lj.si
}

\begin{abstract}
IZVLEČEK
Evropska unija je v letu 2000 v Lizbonsko strategijo zapisala, da želi v desetih letih postati najbolj dinamično in konkurenčno, na znanju temelječe gospodarstvo na svetu, reforma 5 let kasneje pa je kot poglavitna cilja izpostavila ustvarjanje novih in boljših delovnih mest ter vzpostavitev močnejše in trajnejše gospodarske rasti. Namen prispevka je preučiti trenutno stanje Evropske unije in Slovenije na poti do ciljev zastavljenih v prenovljeni Lizbonski strategiji. V analizi želimo ugotoviti kako daleč je EU pri doseganju zastavljenih ciljev ter kako uspešna je bila pri implementaciji strategije na regionalni ravni članic EU. Pri tem se kot osnovno orodje uporablja izračun časovnih distanc ter prikaz časovne prednosti oziroma zaostanka pri doseganju posameznih ciljev Lizbonske strategije na regionalni ravni NUTS 2 razširjene EU in Slovenije.
\end{abstract}

Ključne besede: Lizbonska strategija, kohezijska politika, NUTS 2 regije, Slovenija, časovna distanca

JEL: C10, R10, O10, O52 


\section{Aleksander Aristovnik, Andrej Pungartnik Uresničevanje ciljev Lizbonske strategije na regionalni ravni EU in Slovenija}

\section{Uvod}

Evropska unija (EU) si že od svojih začetkov prizadeva zgraditi gospodarstvo, ki je konkurenčno, napredno, ustvarja delovna mesta in je uravnoteženo med ekonomsko učinkovitostjo in socialno pravičnostjo. Z izvajanjem strukturne in kohezijske politike preko strukturnih skladov, Kohezijskega sklada ter drugih instrumentov Unija že desetletja krepi socialno in ekonomsko kohezijo, s sprejetjem Lizbonske strategije pa se je zavezala $k$ še bolj strukturiranemu ter ambicioznemu zasledovanju ciljev.

Lizbonska strategija je z leti pridobila velik vpliv na oblikovanje in vodenje politik na ravni EU in držav članic. Izvajanje teh politik prispeva k povečanju gospodarske rasti na ravni EU, preko finančnih mehanizmov strukturnih in Kohezijskega sklada pa pospešuje gospodarsko rast $v$ državah članicah, še posebej $\vee$ novih članicah, kar se $\vee$ končni fazi odraža tudi $\vee$ zmanjševanju razlik $\checkmark$ razvitosti med državami in regijami znotraj EU, torej $\vee$ realni konvergenci.

Pri uresničevanju svežnja reform, o katerih so se dogovorili v Lizboni, je bil dosežen določen napredek na državni in evropski ravni, kljub temu pa Evropa še precej zaostaja za načrtovanim. Ob tem je Unija vstopila v nov lizbonski cikel ob upočasnjeni svetovni rasti, ki je zaradi hude finančne krize zajela vse svet. Recesija bo zelo otežila dosego lizbonskih ciljev, toda prav $v$ teh kriznih časih je treba nadaljevati z izvajanjem strategije, saj se lahko le na ta način omilijo učinki recesije. Predvsem je torej pomembno, da se okrepi učinkovito uresničevanje strategije, katerega del je tudi evalvacija sprejetih ukrepov in njihovih rezultatov. Prav metoda časovne distance, ki je uporabljena $v$ tej analizi, je zaradi svoje nazornosti ter preprostosti pomemben člen te evalvacije, saj zelo jasno prikazuje odstopanja dejanskega stanja od ciljev, zapisanih v Lizbonski strategiji na ravni regij in držav. Cilj prispevka je analizirati trenutno stanje Evropske unije in Slovenije na poti do ciljev, zastavljenih $\vee$ Lizbonski strategiji, ter s pomočjo aplikacije Centra za socialne indikatorje ${ }^{\boldsymbol{1}}$ konkretno prikazati, kakšni so zaostanki oziroma prednosti pri zasledovanju posameznih ciljev, izraženi $v$ časovnih distancah na ravni regij NUTS 22 EU ter Slovenije.

1 SICENTER je privatna, neprofitna raziskovalna ustanova. Aktivnost centra se osredotoča predvsem na raziskave in svetovanje na področju analize ekonomskih in socialnih kazalnikov na različnih ravneh agregacije, z aplikacijo $v$ ekonomiji, politiki, poslovnem svetu in statistiki. Vodilni raziskovalec je prof. dr. Pavle Sicherl (Center za socialne indikatorje - SICENTER, 2008).

2 NUTS (fr. Nomenclature des unités territoriales statistiques) je nomenklatura statističnih teritorialnih enot oziroma skupna evropska statistična klasifikacija teritorialnih enot. Omenjeno klasifikacijo je vzpostavil Eurostat, da bi tako zagotovil celovito in dosledno členitev 


\section{Aleksander Aristovnik, Andrej Pungartnik \\ Uresničevanje ciljev Lizbonske strategije na regionalni ravni EU in Slovenija}

\section{Lizbonska strategija}

Zaradi izgubljanja konkurenčne prednosti EU pred Združenimi državami Amerike (ZDA) ter vse hitreje razvijajočimi se azijskimi državami, so se na spomladanskem zasedanju Evropskega sveta v Lizboni leta 2000 voditelji držav in vlad članic Unije dogovorili, da EU potrebuje dolgoročno strategijo. Evropa si je postavila za strateški cilj postati najbolj dinamično in konkurenčno, na znanju temelječe gospodarstvo na svetu, ki ustvarja nova in čedalje boljša delovna mesta, omogoča nenehno gospodarsko rast z večjo socialno kohezijo ter ne nazadnje gospodarstvo, ki spoštuje in varuje okolje (Kok, 2004: 8). Strategija je bila dopolnjena leta 2001 na spomladanskem zasedanju Evropskega sveta v Stockholmu in leta 2002 na zasedanju Evropskega sveta v Barceloni. Švedsko predsedovanje je $\vee$ strategijo vključilo okoljevarstveno razsežnost, špansko predsedovanje pa dalo večji poudarek socialni razsežnosti ter vlaganju $\vee$ raziskave in razvoj (Služba vlade RS za evropske zadeve, 2008).

Zaradi nezadovoljivega napredka in povečanja razlik $v$ potencialu rasti med Evropo ter drugimi gospodarstvi pa je Evropska komisija februarja 2005 državam članicam predlagala spremembe Lizbonske strategije. Revidirana verzija je ponovno opredelila prioritete in metode za njihovo doseganje, najpomembnejša cilja Lizbonske strategije pa sta postala rast in zaposlovanje. Z reformo Lizbonske strategije je bila kot ključni instrument na ravni Skupnosti, ki prispeva k izvajanju strategije za rast in delovna mesta, potrjena kohezijska politika. Poleg ohranjanja socialne kohezije je Evropski svet kot bistvene prednostne naloge za uresničitev lizbonskih ciljev označil še vlaganje $v$ znanje in inovacije, vzpostavitev privlačnega okolja za naložbe in delo ter ustvarjanje več in boljših delovnih mest (Nov začetek za Lizbonsko strategijo, 2005: 7).

Evropska kohezijska politika je z reformo, ki jo je predlagala Komisija, torej postala ena od glavnih politik Skupnosti za uresničitev agende Unije za rast in delovna mesta. Z razširitvijo EU na 27 držav članic in z dramatičnim povečanjem razlik $v$ razvitosti med posameznimi članicami ter regijami pa se je soodvisnost doseganja obeh ciljev, gospodarske rasti in kohezije na ravni Unije še povečala. EU kot celota tako ne bo mogla dosegati višjih stopenj gospodarske

teritorialnih enot, potrebno za zbiranje, razvoj in usklajevanje regionalnih statistik v Evropski uniji. Ker klasifikacija NUTS temelji na hierarhični členitvi, se ozemlja držav delijo na 3 hierarhične ravni: NUTS 1, NUTS 2 ter NUTS 3, pri čemer države pri razdelitvi svojega ozemlja na enote NUTS upoštevajo normativna merila (število prebivalcev), ki so določena $v$ uredbi o NUTS (NUTS, 2008). 


\section{Aleksander Aristovnik, Andrej Pungartnik \\ Uresničevanje ciljev Lizbonske strategije na regionalni ravni EU in Slovenija}

rasti, kot jih dosega sedaj, $v$ kolikor nove članice ne bodo nadaljevale z doseganjem stopenj gospodarske rasti, ki bo bistveno višja od povprečja Unije. Visoka gospodarska rast $v$ manj razvitih delih EU je pomembna za sočasno doseganje obeh ciljev, realne konvergence manj razvitih regij Skupnosti in povečevanja gospodarske rasti $\vee$ EU kot celoti. $\vee$ tem kontekstu je logično, da naj bi EU v srednjeročnem obdobju 2007-2013 usmerjala kohezijska sredstva predvsem za namene, ki bodo zagotavljali trajnostno gospodarsko rasti, konkurenčnost gospodarstva in zaposlovanje, kot je to predvideno $\vee$ prenovljeni Lizbonski strategiji (Nacionalni strateški referenčni okvir 2007-2013, 2007: 3).

\section{Učinki kohezijske politike na ravni NUTS 2 regij EU}

Eden od glavnih ciljev kohezijske politike je zmanjšanje ekonomskih in socialnih razlik $v$ razvoju med evropskimi regijami. Regije, ki zaostajajo $v$ razvoju, morajo ostati $v$ središču politike, ki pa mora zajeti celotno ozemlje EU, glede na to, da je cilj kohezijske politike tudi spodbujanje lastnega razvojnega potenciala evropskih regij. Učinke kohezijske politike EU je iz več razlogov težko natančno izmeriti. Jones (2001: 247) omenja tri glavne vzroke, zakaj je temu tako: prvič, vse učinke nekaterih programov in projektov je mogoče videti le na dolgi rok, drugič, tako na regionalne, kot nacionalne ekonomije vpliva cela vrsta faktorjev in je težko določiti natančen vpliv posameznega faktorja in tretjič, obstaja tudi problem ločevanja vpliva politike EU od vplivov nacionalnih regionalnih politik. Navkljub velikemu trudu EU tako še vedno obstajajo velike razlike $\vee$ BDP na prebivalca med državami članicami ter med njihovimi regijami. Konvergenca med evropskimi regijami je $v$ zadnjih letih sicer dokaj močna, zaradi česar so se zmanjšala neskladja $\vee$ BDP na prebivalca. ${ }^{3}$ Do te usmeritve so $\vee$ glavnem privedla izboljšanja $\vee$ najmanj uspešnih regijah, ob tem pa lahko zmanjšanje razlik pripišemo tudi počasnejši stopnji rasti BDP $\vee$ najrazvitejših regijah. Naslednja analiza je narejena na ravni regij NUTS 2.

3 To je realna konvergenca, ki pomeni približevanje ravni gospodarske razvitosti, ki ga običajno predstavlja kazalnik bruto domači proizvod na prebivalca (merjen po pariteti kupne moči). Analiziranje realne konvergence med državami (regijami) s tem kazalnikom dejansko pomeni oceno, ali se BDP na prebivalca neke države, regije ali skupine držav približuje povprečni vrednosti omenjenega kazalnika za vse primerjane države (regije) (Martín, 2001: 7). 


\section{Aleksander Aristovnik, Andrej Pungartnik \\ Uresničevanje ciljev Lizbonske strategije na regionalni ravni EU in Slovenija}

$\checkmark$ tabeli 1 lahko vidimo, da so imele leta 2000 najbogatejše regije, ki pomenijo $10 \%$ prebivalcev EU-15, BDP na prebivalca višji od povprečja EU za skoraj $92 \%$, medtem ko so imele najrevnejše regije, v katerih živi $10 \%$ prebivalstva EU-15, BDP na prebivalca nižji od povprečja EU za več kot $32 \%$. Če to izrazimo s koeficientom, lahko rečemo, da je bil BDP najbogatejših regij (10 $\%+)$ v letu 2000 2,8 krat višji od tistega $\vee$ najrevnejših regijah (10 \%-). V letu 2005 je ta koeficient znašal 2,7, kar pomeni, da so se razlike med najbogatejšimi in najrevnejšimi regijami $v$ tem obdobju nekoliko zmanjšale, vendarle pa ni bilo občutnejšega izboljšanja, zaradi česar je tudi prišlo do reforme kohezijske politike in popravkov strategije.

Tabela 1: Najbolj in najmanj razvite regije EU glede na BDP p.c. v obdobju 2000-2005

\begin{tabular}{|l|c|c|c|c|}
\hline \multirow{2}{*}{ Regije } & \multicolumn{2}{|c|}{ EU-15 } & \multicolumn{2}{c|}{ EU-27 } \\
\cline { 2 - 5 } $10 \%+$ & 2000 & 2005 & 2000 & 2005 \\
\cline { 2 - 5 } $10 \%-$ & 191,6 & 187,7 & 184,7 & 173,8 \\
Koeficient & 67,6 & 70,0 & 30,9 & 36,7 \\
$25 \%+$ & 2,8 & 2,7 & 6,0 & 4,7 \\
$25 \%-$ & 160,0 & 156,0 & 150,9 & 149,9 \\
Koeficient & 79,1 & 79,8 & 47,9 & 52,8 \\
\hline
\end{tabular}

Opomba: podatki se nanašajo na BDP na prebivalca, merjenega po pariteti kupne moči; vrednost BDP je izražena kot \% povprečnega BDP Evropske unije; $10 \%+$ in $25 \%+$ se nanaša na regije z najvišjim BDP na prebivalca, ki skupaj predstavljajo 10 oziroma $25 \%$ celotne populacije EU; $10 \%$ - in $25 \%$ - se nanaša na regije z najnižjim BDP na prebivalca, ki skupaj predstavljajo 10 oziroma $25 \%$ celotne populacije EU.

Vir: Eurostat; lastni izračuni.

Tabela nam tudi pokaže, da so se razlike med regijami v EU z vstopom novih članic še izrazito povečale. Vidimo lahko, do kakšne spremembe pride, če v letu 2000 povečamo število držav na 27 (torej zajamemo še 10 kandidatk, ki so $\checkmark$ EU vstopile leta 2004, ter Bolgarijo in Romunijo) ter kako to vpliva na koeficiente. Ugotovimo, da so imele najrevnejše regije, v katerih živi $10 \%$ prebivalcev EU-27, v letu 2000 BDP na prebivalca za skoraj $70 \%$ pod evropskim povprečjem. Vrednost koeficienta je $v$ letu 2000 znašala 6,0, kar pomeni, da je bil BDP najbogatejših regij (10 \%+ EU-27) 6-krat višji od tistega $\vee$ najrevnejših regijah (10\%-EU-27). Razlike med regijami so se torej z vstopom novih članic 
Aleksander Aristovnik, Andrej Pungartnik

Uresničevanje ciljev Lizbonske strategije na regionalni ravni EU in Slovenija

še dodatno povečale, je pa v obdobju petih let koeficient padel na 4,7, kar kaže na to, da so najrevnejše regije na ravni EU-27 naredile korak naprej, ob tem pa je na zmanjšanje koeficienta vplivalo tudi znižanje povprečja BDP na prebivalca $\checkmark$ najrazvitejših regijah glede na povprečje Unije. Seveda so razlike med najbolj in najmanj razvitimi regijami še izjemno velike in treba bo še veliko časa, da se bodo najslabše razvite regije približale povprečju EU.

Zanimivo je tudi pogledati, kje je mesto Slovenije v primerjavi z najbolj in najmanj razvitimi regijami EU. Ozemlje RS se sicer od leta 2009 na ravni NUTS 2 deli na dve kohezijski regiji - Vzhodno Slovenijo in Zahodno Slovenijo. Na ravni NUTS 1 Slovenija še vedno nastopa kot celota, na ravni NUTS 3 pa se tako kot prej členi na 12 statističnih regij.

Tabela 2: Razvitost Slovenije na nivoju regij NUTS 2 glede na BDP p.c. v obdobju 2000-2005 (EU-27=100)

\begin{tabular}{|l|c|c|}
\hline \multirow{2}{*}{ Slovenija } & \multicolumn{2}{|c|}{ Slovenija } \\
\cline { 2 - 3 } & 2000 & 2005 \\
\cline { 2 - 3 } Vzhodna Slovenija & 79,8 & 87,4 \\
Zahodna Slovenija & 67,3 & 72,5 \\
\hline
\end{tabular}

Opomba: podatki se nanašajo na BDP na prebivalca, merjenega po pariteti kupne moči; Vzhodna Slovenija: Pomurska, Podravska, Koroška, Savinjska, Zasavska, Spodnjeposavska, Jugovzhodna Slovenija, Notranjsko-kraška; Zahodna Slovenija: Osrednjeslovenska, Gorenjska, Goriška, Obalno-kraška.

Vir: Eurostat, lastni izračuni.

Iz tabele 2 je razvidno, da je imela v letu 2000 Slovenija BDP na prebivalca nižji od povprečja EU-27 za dobrih 20 \%, v letu 2005 pa le še dobrih $12 \%$. Se pa zelo velike razlike kažejo na ravni regij NUTS 2, kjer je $v$ letu 2005 Zahodna Slovenija že presegala povprečno razvitost Unije, medtem ko je Vzhodna Slovenija za tem znatno zaostajala. Tudi znotraj Slovenije torej obstajajo velike razlike $\vee$ razvitosti glede na BDP na prebivalca, razlike pa so se $\vee$ omenjenem obdobju med regijama še povečevale, zato predvsem na področju Vzhodne Slovenije čaka našo državo še veliko dela. 


\section{Aleksander Aristovnik, Andrej Pungartnik \\ Uresničevanje ciljev Lizbonske strategije na regionalni ravni EU in Slovenija}

Vidimo torej lahko, kako je vključitev novih držav še dodatno otežila doseganje lizbonskih ciljev in kako zelo velike razlike so med regijami na ravni EU. $V$ preučevanem obdobju večina teh najmanj razvitih regij sicer ni bila del Unije, toda namen analize je predvsem prikazati ogromne razlike $v$ razvitosti regij ter pokazati, koliko dejansko najmanj razvite regije zaostajajo za najbolj razvitimi. Glavna naloga kohezijske politike je zmanjševanje neenakosti med regijami Unije in ti rezultati kažejo, da bo treba vložiti še veliko napora, da se bodo razlike zmanjšale in se bodo tudi najmanj razvite regije približale najbolj razvitim. Koliko pa dejansko znašajo zaostanki na ravni regij NUTS 2 za lizbonskimi cilji, ugotavljamo z metodo računanja časovnih distanc.

\section{Izračunavanje časovnih distanc in odstopanj od ciljev lizbonske strategije}

\section{1 Časovna distanca}

Časovna distanca je $v$ splošnem razdalja $v$ času med dvema dogodkoma. S-distanca pa je posebna kategorija časovne distance, ki je definirana za dano raven spremenljivke (kazalnika). $V$ nasprotju s statičnimi merami, ki so opredeljene glede na določeno časovno enoto, je S-distanca opredeljena za določeno raven spremenljivke in meri razliko $v$ času, ko primerjani enoti dosežeta dano raven opazovane spremenljivke. Tako določeno distanco $v$ času (npr. število let, mesecev, dni, itd.) uporabljamo kot dinamično (časovno) mero neenakosti med opazovanima enotama $v$ istem smislu, kot določeno razliko (absolutno ali relativno) $v$ določenem trenutku uporabljamo kot statično mero razlik med opazovanima enotama (Sicherl, 2003: 188). ${ }^{4}$

Za računanje S-časovne distance na makro ravni sta potrebni dve časovni seriji: časovna serija dejanskih vrednosti kazalnika ter časovna serija predvidenih ciljnih vrednosti (linija do cilja). Časovna distanca je razlika med dejanskim časom ter časom na liniji do cilja za vsako dejansko vrednost spremenljivke (Sicherl, 2008: 2):

$$
\begin{aligned}
& S\left(X_{t}\right)=\text { dejanski čas } t-\text { čas na ciljni črti } T \text { za vsako dejansko vrednost spremenljivke } X_{t} \\
& S\left(X_{t}\right)=t\left(X_{t}\right)-T\left(X_{t}\right)
\end{aligned}
$$

4 Več o časovni distanci glej tudi v Granger (1997, 2003). 
Aleksander Aristovnik, Andrej Pungartnik

Uresničevanje ciljev Lizbonske strategije na regionalni ravni EU in Slovenija

Časovna distanca ima kot komplementarna mera konvencionalnim meram razlik zelo obsežno potencialno uporabo pri analizi časovno opredeljenih podatkov pri primerjavah med raznimi enotami, pri regresijah, modelih, predvidevanjih in monitoringu. Po drugi strani pa predlagana metodologija uvaja nov pogled na stopnjo neenakosti $\vee$ razvoju in blaginji in s tem boljšo analitično podlago za vrednostne sodbe, ki jih o svoji relativni poziciji v družbi in svetu oblikujejo posamezniki in skupine na različnih ravneh, kakor tudi za nove hipoteze o načinih povezovanja problemov rasti in problemov neenakosti $v$ teoriji in praksi. Ta povezava pa je ena od ključnih točk evropske razvojne paradigme, kot je izražena v Lizbonski strategiji (Sicherl, 2003: 203).

Namen uvajanja časovne distance $v$ analizo razlik ni $v$ nadomestitvi običajno uporabljanih statičnih metod in meritev, temveč $v$ njihovi dopolnitvi in razširitvi celotnega teoretskega in metodološkega pristopa. Uporaba koncepta časovne distance in njena operacionalizacija s pomočjo statistične mere Sdistance omogočata kot dodatni instrumentarij k obstoječim metodam analize dodatno razumevanje problema in izboljšave na dveh področjih, konceptualnem in analitičnem. Prednost S-distance je, da je izražena $v$ enotah časa ter tako razumljiva vsem, dodatna prednost pa je lastnost, da vse dosedanje metode in rezultati (ne pa nujno tudi zaključki) ostanejo nespremenjeni, saj časovna distanca dodaja novo dimenzijo in ne nadomešča drugih pogledov (Sicherl, 2003: 189).

\subsection{Izračun napredka/zaostanka pri doseganju ciljev Lizbonske strategije na ravni regij NUTS 2}

Dodaten pogled na stopnjo uresničevanja Lizbonske strategije glede na postavljene EU ali nacionalne cilje je razvil Center za socialne indikatorje. Pripravil je spletno aplikacijo za enostavno računanje časovnih distanc in odstopanj od ciljev na podlagi katere je narejena tudi naslednja analiza. $V$ njej je S-časovna distanca (izražena $v$ enotah časa) uporabljena na primeru lizbonskih ciljev na regionalni ravni za EU in Slovenijo. Za dejansko vrednost $v$ določenem letu ugotavljamo, kdaj naj bi bila ta vrednost dosežena na postavljeni liniji do cilja, časovna distanca pa izraža prednost ali zaostanek v času glede na linijo do cilja.

$\checkmark$ analizi računamo povprečno časovno distanco za najbolj ter najmanj razvite regije NUTS 2 na ravni EU-27 ter Slovenije. Tudi tu velja, da med najbolj razvite regije uvrščamo regije $z$ najvišjim BDP na prebivalca, ki skupaj pomenijo $10 \%$ celotne populacije EU-27, med najmanj razvite pa regije z najnižjim BDP na prebivalca, ki skupaj pomenijo 10 \% celotne populacije EU-27. Naj omenimo, da je 


\section{Aleksander Aristovnik, Andrej Pungartnik \\ Uresničevanje ciljev Lizbonske strategije na regionalni ravni EU in Slovenija}

zaradi pomanjkanja podatkov na regionalni ravni merjenje časovne distance za posamezne kazalnike onemogočeno oziroma zelo oteženo. Tako na primer ni mogoče sledenje cilju deleža BDP namenjenega raziskavam in razvoju, ki je eden temeljnih lizbonskih ciljev, so pa izračunane časovne distance za cilja $70 \%$ stopnje zaposlenosti v EU ter $3 \%$ povprečne letne rasti BDP EU do leta 2010. Poudariti je treba tudi, da je $v$ primeru neobstoja podatkov za določeno regijo, ki po svoji razvitosti (nerazvitosti) sicer spada med 10\% najbolj (najmanj) razvitih regij na ravni EU27, ta bila zamenjana z naslednjo v nizu, za katero so podatki na voljo.

\subsubsection{Lizbonski cilj na ravni regij NUTS 2: 70 \% stopnja zapo- slenosti v Evropski uniji do leta 2010}

Med najbolj razvite regije $(10 \%+)$ so uvrščene večinoma regije iz starejših članic, predvsem Nemčije, Anglije, Belgije, Nizozemske, iz novink prihajata le dve, in sicer, Praga ter Bratislava. Povprečna stopnja zaposlenosti najbolj razvitih regij je že leta 2000 znašala 68,5 \%, torej je bila zelo blizu ciljne vrednosti, in je po manjšem upadanju do leta 2004 v zadnjih dveh obravnavanih letih spet dosegala pozitiven trend. Prav ta pozitivni zasuk v letih 2005 in 2006 se je dobro odrazil tudi na časovno distanco, saj je ta $\vee$ zadnjem obravnavanem letu znašala le še 2,5 let.

Slika 1: Časovna distanca $10 \%+$ regij EU-27 pri sledenju cilja 70 \% stopnje zaposlenosti EU do leta 2010

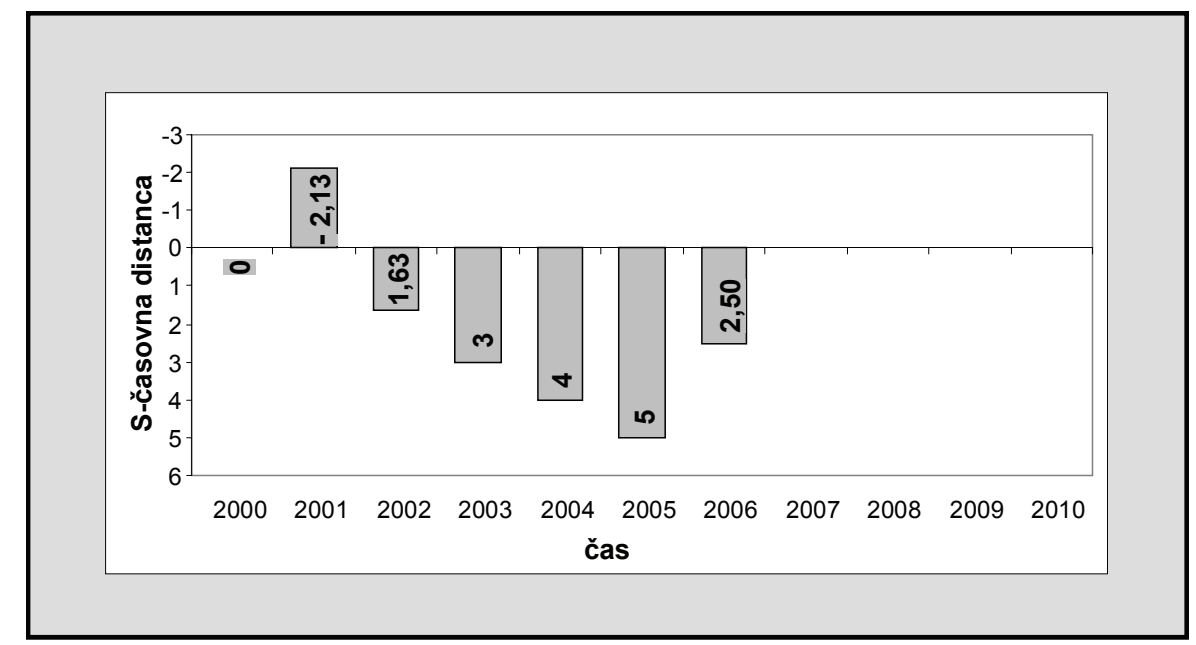

Legenda: (-) časovna prednost (pred linijo do cilja), (+) časovni zaostanek (za linijo do cilja). Vir: Eurostat; lastni izračuni. 
Aleksander Aristovnik, Andrej Pungartnik

Uresničevanje ciljev Lizbonske strategije na regionalni ravni EU in Slovenija

Popolnoma drugačna je slika za najmanj razvite regije, večinoma iz Bolgarije, Romunije in Poljske, ki imajo najnižji BDP na prebivalca in skupaj predstavljajo $10 \%$ celotne populacije EU-27. V letu 2000 je povprečna stopnja zaposlenosti za te znašala slabih $56,9 \%$ in $v$ naslednjih 6 letih te vrednosti ni več dosegla. Časovna distanca se je $\vee$ zajetem obdobju konstantno povečevala ter je $\vee$ zadnjem obravnavanem letu znašala 6 let.

Slika 2: Časovna distanca $10 \%$ - regij EU-27 pri sledenju cilja 70 \% stopnje zaposlenosti EU do leta 2010

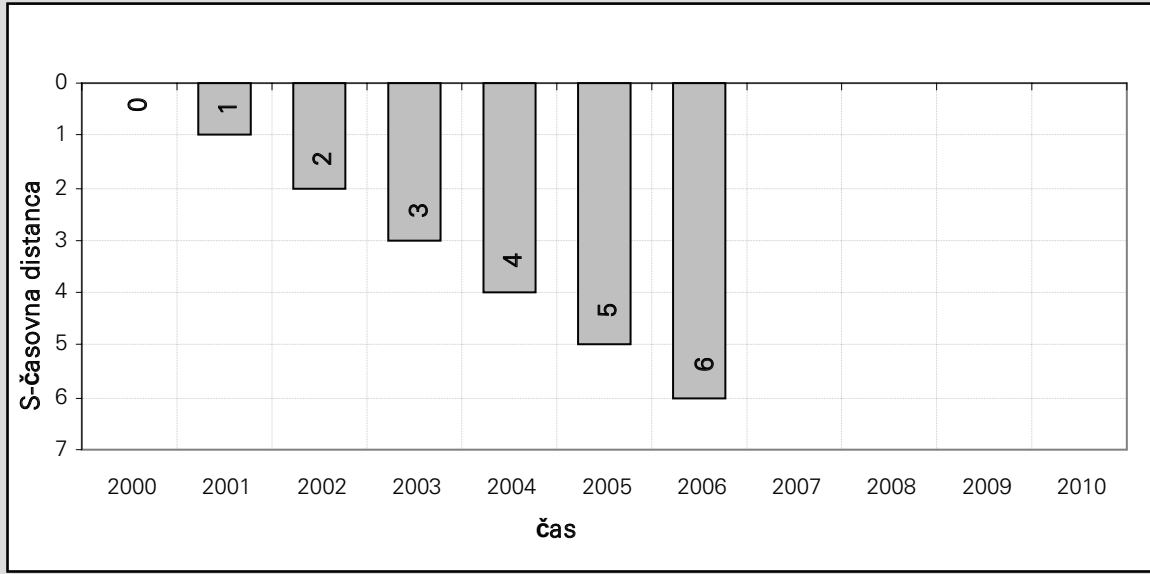

Legenda: (-) časovna prednost (pred linijo do cilja), (+) časovni zaostanek (za linijo do cilja). Vir: Eurostat; lastni izračuni.

\subsubsection{Lizbonski cilj na ravni regij NUTS 2: $3 \%$ povprečna let- na rast BDP Evropske unije do leta 2010}

Tako kot na ravni držav tudi pri regijah pričakujemo, da bodo manj razvite regije rastle hitreje kot bolj razvite, saj le tako prihaja do konvergence in zmanjševanja razlik $v$ razvitosti. Za najmanj razvite regije torej pričakujemo negativne časovne distance oziroma prednost pred ciljnimi vrednostmi, za najbolj razvite pa zaostanke ter pozitivne distance. 
Slika 3: Časovna distanca $10 \%+$ regij EU-27 pri sledenju cilja $3 \%$ povprečne letne rasti BDP EU

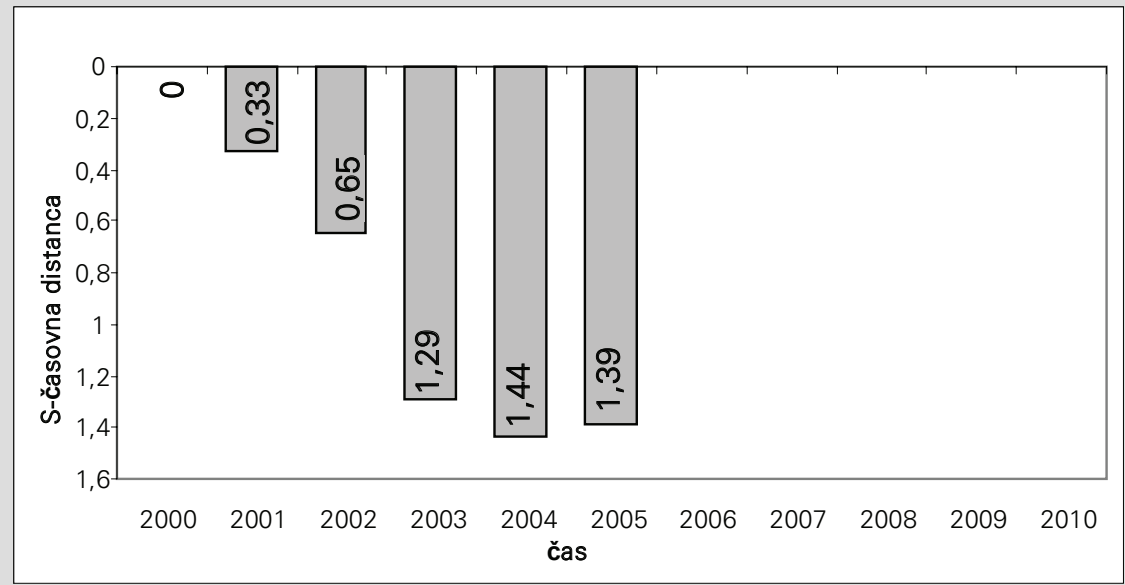

Legenda: (-) časovna prednost (pred linijo do cilja), (+) časovni zaostanek (za linijo do cilja). Vir: Eurostat; lastni izračuni.

Že od samega začetka uvajanja Lizbonske strategije je povprečna letna rast najbolj razvitih regij $(10 \%+)$ zaostajala za ciljnimi vrednostmi, slika 3 pa kaže, da se je v zadnjih dveh obravnavanih letih (zaradi pomanjkanja podatkov je zadnje zajeto leto 2005) zaostanek ustalil na približno 1,4 leta. V letu 2005 je tako časovna distanca znašala 1,39 let.

Drugače je pri sledenju cilja 3 \% povprečne letne stopnje rasti BDP za najmanj razvite regije $(10 \%-)$, saj povprečna stopnja sledi oziroma prehiteva ciljne vrednosti. V prvih dveh letih sicer obstaja manjši zaostanek, toda od leta 2003 naprej je časovna distanca negativna, kar pomeni prednost pred ciljno vrednostjo. V letu 2005 se je distanca sicer nekoliko zmanjšala glede na predhodno leto, toda še vedno je prednost znašala 1,25 let. 
Aleksander Aristovnik, Andrej Pungartnik

Uresničevanje ciljev Lizbonske strategije na

regionalni ravni EU in Slovenija

Slika 4: Časovna distanca 10\%- regij EU-27 pri sledenju cilja 3 \% povprečne letne rasti BDP EU

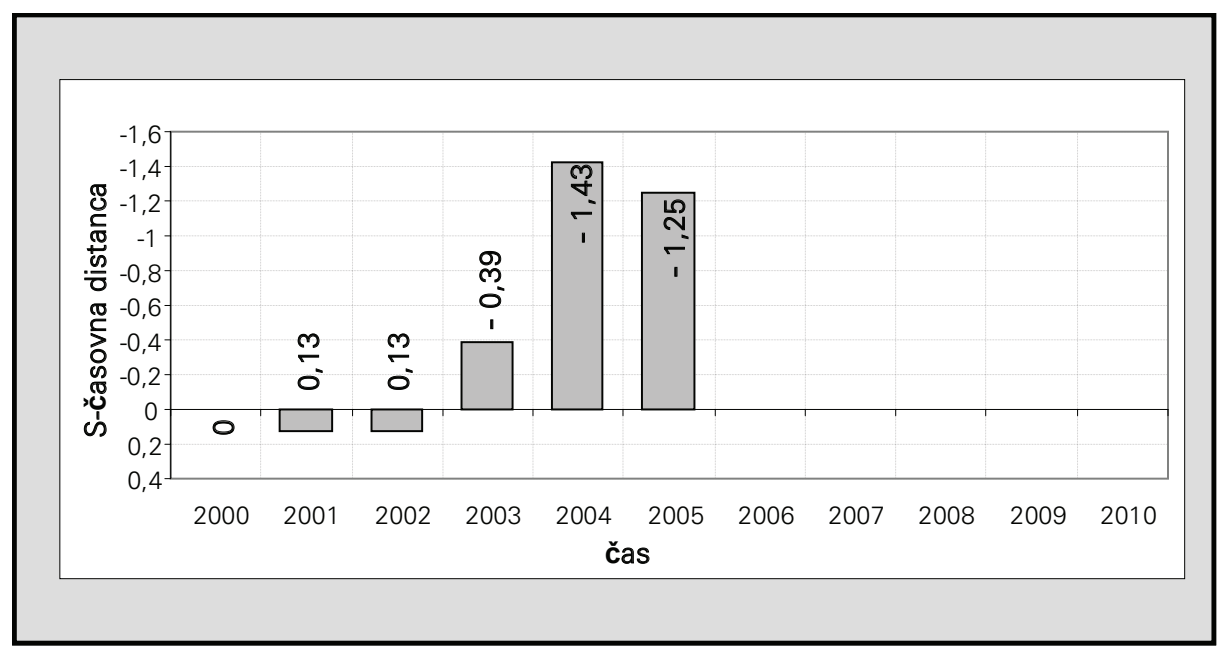

Legenda: (-) časovna prednost (pred linijo do cilja), (+) časovni zaostanek (za linijo do cilja).

Vir: Eurostat; lastni izračuni.

Če povzamemo rezultate za obravnavane cilje $\vee$ tabelo (tabela 3), jih je smiselno primerjati $z$ rezultati na ravni EU-15, saj na ta način $v$ analizo zajamemo le regije, ki so bile $\vee$ celotnem obravnavanem obdobju del Unije. Glede na to, da se tako na ravni EU-27 kot tudi EU-15 med najbolj razvite regije uvrščajo večinoma regije iz petnajsterice, večjih razlik $v$ samih rezultatih pri najbolj razvitih regijah nismo pričakovali, kar potrjujejo tudi časovne distance. Drugače je pri najmanj razvitih regijah, saj se med $10 \%$ najmanj razvitih regij na ravni EU-27 uvrščajo večinoma regije iz novo pridruženih članic (Romunije, Bolgarije, Poljske), medtem je na ravni EU-15 večina teh regij iz sredozemskih držav (Grčije, Italije, Španije, Francije). Pri sledenju cilja 70 \% stopnje zaposlenosti do leta 2010 je časovna distanca $\vee 10$ \%- regijah EU-27 v letu 2006 znašala 6 let, na ravni EU-15 pa 4,57 let. Stopnje zaposlenosti v najmanj razvitih regijah $\vee$ novih članicah so zelo nizke in se ne povečujejo, kar vpliva tudi na povečevanje zaostanka za lizbonskim ciljem, medtem ko je na ravni EU-15 opaziti manjšo rast stopnje, ki pa zaostaja za ciljno stopnjo, zaradi česar distanca prav tako $v$ obravnavanem obdobju narašča. Iz dobljenih podatkov lahko ugotovimo, da obstajajo znatne razlike $v$ zaposlenosti med najbolj in najmanj razvitimi regijami, kar kažejo tudi razlike $\vee$ časovnih distancah, je pa predvsem zaskrbljujoč trend $v$ najmanj razvitih regijah novih članic, kjer zaradi padca stopenj zaposlenosti $\vee$ zajetem obdobju časovne distance ter $\mathrm{s}$ tem zaostanki za 
Aleksander Aristovnik, Andrej Pungartnik

Uresničevanje ciljev Lizbonske strategije na regionalni ravni EU in Slovenija

lizbonskim ciljem hitro naraščajo. Med regijami, ki dosegajo najvišje zaostanke pri cilju 70 \% stopnje zaposlenosti do leta 2010 so na ravni EU-27 na dnu pričakovano bolgarske, madžarske, romunske ter poljske regije, na ravni EU-15 pa francoski čezmorski departmaji in grški otoki, kar je $v$ veliki meri posledica njihove geografske odmaknjenosti, ter regije južne Španije, Italije in vzhodne Nemčije. Regije, ki dosegajo največje prednosti, izhajajo iz najrazvitejših držav, kot so Anglija (London, Berkshire, Bucks and Oxfordshire), Avstrija (Salzburg, Dunaj), Švedska (Stockholm), med zajetimi regijami pa se iz novo pridruženih članic sem uvrščata le Bratislava ter Praga.

Tabela 3: Časovne distance najbolj $(10 \%+)$ in najmanj (10\%-) razvitih regij (NUTS 2 ) na nivoju EU-27 in EU-15 pri sledenju ciljev Lizbonske strategije

\begin{tabular}{|l|c|c|c|c|c|c|c|c|}
\hline \multicolumn{7}{|c|}{ S-časovna distanca v letih } \\
\hline Cilji & 2000 & 2001 & 2002 & 2003 & 2004 & 2005 & 2006 \\
\hline Cilj 1 & 0 & $-2,13$ & 1,63 & 3 & 4 & 5 & 2,5 \\
\hline $10 \%+$ regije EU-27 & 0 & 1 & 2 & 3 & 4 & 5 & 6 \\
$10 \%$ - regije EU-27 & 0 & $-3,36$ & 1,23 & 3 & 4 & 5 & 3,32 \\
$10 \%+$ regije EU-15 & 0 & 0,95 & 1,57 & 2,38 & 2,97 & 3,88 & 4,57 \\
\hline $10 \%$ - regije EU-15 & 0 & 0,33 & 0,65 & 1,29 & 1,44 & 1,39 & $n p$ \\
\hline $10 \%$ - regije EU-15 & 0 & $-0,20$ & 0,39 & 0,70 & 1,07 & 1,80 & $n p$ \\
\hline $10 \%$ - regije EU-27 & 0 & 0,13 & 0,13 & $-0,39$ & $-1,43$ & $-1,25$ & $n p$ \\
\hline
\end{tabular}

Legenda: Cilj 1: 70 \% stopnja zaposlenosti v EU do 2010; Cilj 2: 3 \% povprečna letna rast BDP EU; np- ni podatka.

Vir: Eurostat; lastni izračuni. 


\section{Aleksander Aristovnik, Andrej Pungartnik \\ Uresničevanje ciljev Lizbonske strategije na regionalni ravni EU in Slovenija}

Pri sledenju cilja $3 \%$ povprečne letne rasti BDP zaradi pomanjkanja podatkov preučujemo le obdobje od leta 2000 do 2005. Tudi tu večjih razlik med časovnimi distancami najbolj razvitih regij na ravni EU-27 in EU-15 ni. Je pa pri obeh ugotovljen zaostanek za ciljem, ki se je $v$ petletnem obdobju konstantno povečeval. Glede na to, da med 10\%+ regije spadajo najbolj razvite regije, je razumljivo, da le-te težko dosegajo $3 \%$ povprečno letno ciljno stopnjo rasti BDP, saj je njihov BDP na prebivalca že na izjemno visoki ravni, kar otežuje visoke povprečne stopnje rasti. Na drugi strani je časovna distanca regij z najnižjim BDP na prebivalca, ki skupaj pomenijo $10 \%$ celotne populacije EU-27, negativna, kar pomeni prednost pred linijo do cilja. V letu 2005 je ta znašala 1,25 let. Na ravni EU-15 je drugače, saj tam najmanj razvite regije zaostajajo za linijo do cilja, zaostanek v letu 2005 je tako znašal 1,8 let. Glede na mnogo slabšo razvitost $10 \%$ - regij EU-27 $\vee$ primerjavi z najmanj razvitimi regijami na ravni EU-15 so razlike razumljive, saj imajo najmanj razvite regije sedemindvajseterice še ogromno potenciala za rast, zato je doseganje visokih povprečnih letnih stopenj rasti BDP lažje. Najhitreje rastoče regije so tako pogosto pomembnejša urbana območja in regijske prestolnice (London, Luksemburg, Praga, Bratislava), visoke stopnje rasti pa so opažene tudi v regijah, kjer je bila zelo nizka raven BDP na prebivalca, kot na primer, bolgarska regija Yugozapaden, romunska regija Bucuresti-lifov itd. Na drugi strani so nizke stopnje rasti ter s tem zaostanek za ciljem $3 \%$ povprečne letne rasti BDP predvsem značilne za regije z visokim BDP na prebivalca $\vee$ Franciji, Nemčiji, Italiji, na Finskem, Švedskem in Danskem.

\subsubsection{Lizbonski cilj za Slovenijo: 70 \% stopnja zaposlenosti do leta 2010}

Rezultate časovnih distanc na evropskem regionalni ravni pa je zanimivo primerjati tudi z rezultati na ravni Slovenije. Pri tem je treba poudariti, da je zaradi neobstoja podatkov na ravni NUTS 2 na področju stopnje zaposlenosti za posamezne članice analiza za Slovenijo narejena le na ravni celotne države. Za cilj 70 \% stopnje zaposlenosti do leta 2010 ugotovimo, da so časovni zaostanki za ciljnimi vrednostmi mnogo manjši $\vee$ primerjavi s časovnimi distancami $\vee$ najbolj in najmanj razvitih regijah EU-27 ter EU-15. 
Aleksander Aristovnik, Andrej Pungartnik

Uresničevanje ciljev Lizbonske strategije na

regionalni ravni EU in Slovenija

V letu 2006 je sicer opazen nekoliko večji zaostanek glede na predhodna leta, a vseeno znaša le 0,59 let (slika 5), kar je mnogo bolje od časovnih distanc na ravni evropskih regij NUTS 2, tako v primerjavi z najbolj razvitimi regijami kot tudi z najmanj razvitimi, kjer so pričakovano zaostanki mnogo večji.

Slika 5: Časovna distanca Slovenije pri sledenju cilja $70 \%$ stopnje zaposlenosti do leta $\mathbf{2 0 1 0}$

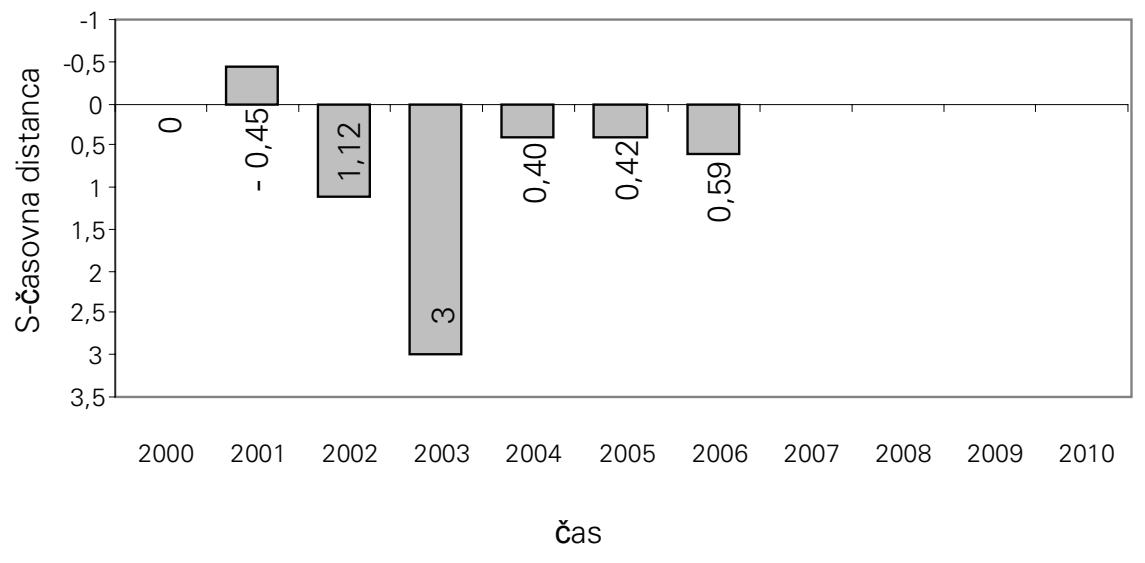

Legenda: (-) časovna prednost (pred linijo do cilja), (+) časovni zaostanek (za linijo do cilja). Vir: Eurostat; lastni izračuni.

\subsubsection{Lizbonski cilj za Slovenijo: 3 \% povprečna letna rast BDP do leta 2010}

Pri cilju 3 \% povprečne letne rasti BDP Slovenija, kot novo pridružena mlada članica, $v$ primerjavi s povprečjem EU dosega dobre rezultate, ki so blizu rezultatov najmanj razvitih regij na ravni EU-27. Že od vsega začetka dejanske vrednosti prehitevajo ciljne, kar se odraža tudi $\vee$ rezultatih časovne distance (slika 6). Slovenija je imela tako $v$ letu 2006 skoraj dvoletno $(1,97)$ časovno prednost, ki se je povečevala $\vee$ zadnjih treh zajetih letih. 
Aleksander Aristovnik, Andrej Pungartnik

Uresničevanje ciljev Lizbonske strategije na

regionalni ravni EU in Slovenija

\section{Slika 6: Časovna distanca Slovenije pri sledenju cilja $3 \%$ povprečne letne rasti BDP}

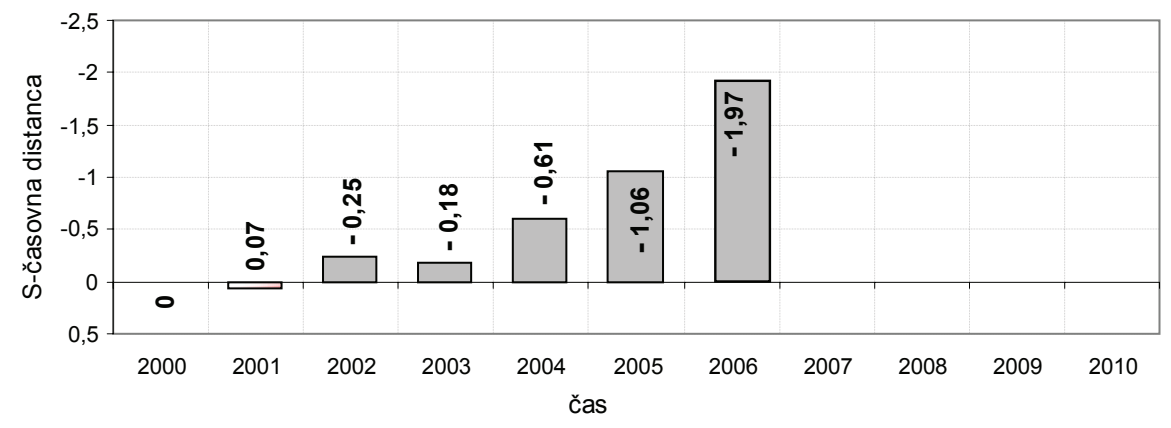

Legenda: (-) časovna prednost (pred linijo do cilja), (+) časovni zaostanek (za linijo do cilja). Vir: Eurostat; lastni izračuni.

Zanimiv je tudi pogled na zasledovanje tega cilja na nivoju NUTS 2. Časovna distanca za Zahodno Slovenijo se v zajetem obdobju stalno zmanjšuje, kar pomeni povečevanje prednosti pred ciljnimi vrednostmi. V letu 2005 je tako prednost znašala 1,47 let.

\section{Slika 7: Časovna distanca Zahodne Slovenije pri sledenju cilja 3 \%} povprečne letne rasti BDP

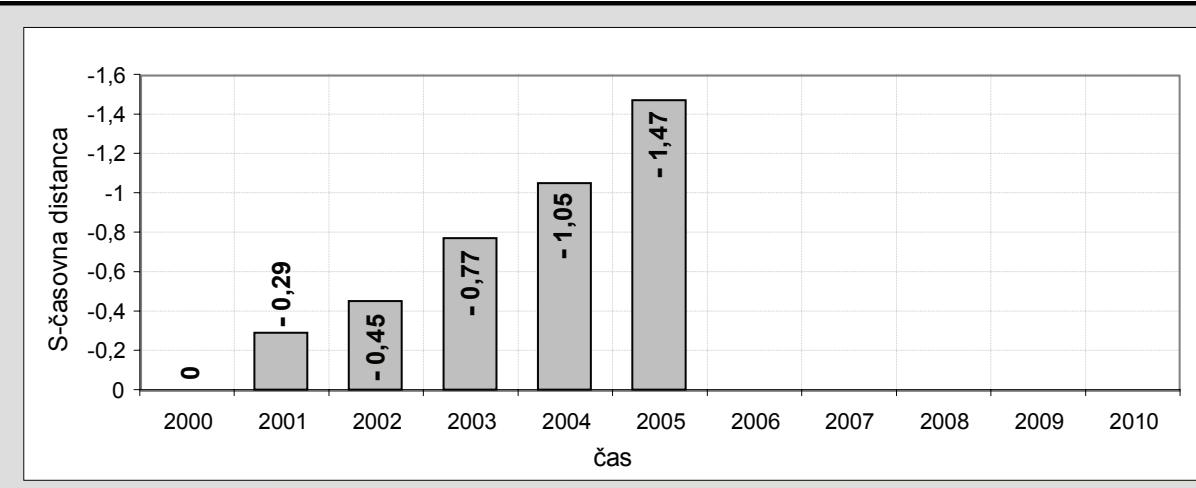

Legenda: (-) časovna prednost (pred linijo do cilja), (+) časovni zaostanek (za linijo do cilja). Vir: Eurostat; lastni izračuni. 


\section{Aleksander Aristovnik, Andrej Pungartnik \\ Uresničevanje ciljev Lizbonske strategije na regionalni ravni EU in Slovenija}

Nekoliko slabše je stanje v regiji Vzhodna Slovenija, ki sicer v zadnjih dveh obravnavanih letih tudi dosega prednost, toda ta je manjša kot $\vee$ Zahodni Sloveniji. Glede na stanje v državi so rezultati časovnih distanc za cilj povprečne letne stopnje rasti BDP na ravni NUTS 2 v Sloveniji pričakovano ugodnejši $v$ zahodnem delu, ki razpolaga z boljšo infrastrukturo, visoko kvalificirano delovno silo in s tem z boljšimi priložnostmi za razvoj, kar posledično pomeni tudi višjo povprečno gospodarsko rast ter ugodnejše časovne distance.

Slika 8: Časovna distanca Vzhodne Slovenije pri sledenju cilja $3 \%$ povprečne letne rasti BDP

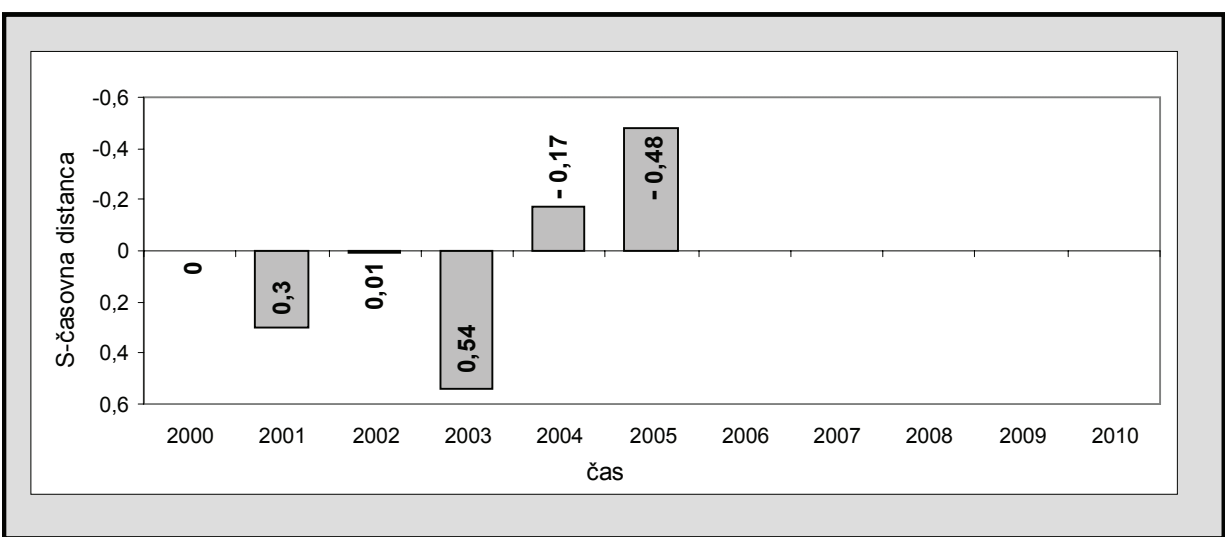

Legenda: (-) časovna prednost (pred linijo do cilja), (+) časovni zaostanek (za linijo do cilja). Vir: Eurostat; lastni izračuni.

Na ravni Slovenije so rezultati pri sledenju ciljev torej bolj ugodni. Pri sledenju cilja 70 \% stopnje zaposlenosti do leta 2010 so rezultati časovnih distanc $\checkmark$ primerjavi s povprečnimi časovnimi distancami najbolj in najmanj razvitih evropskih regij NUTS 2 spodbudni. Leta 2006 je tako zaostanek znašal 0,59 let. Zadnji podatki pa kažejo, da je v letu 2007 zaostanek celo prerastel v prednost, saj je dejanska stopnja zaposlenosti presegla ciljno, s čimer je bila Slovenija na dobri poti, da bi v letu 2010 dosegla oziroma presegla zastavljeni cilj $70 \%$ stopnje zaposlenosti, toda globalna recesija ter $s$ tem upočasnjena gospodarska rast in povečanje brezposelnosti, bodo zelo otežile oziroma onemogočile dosego ciljev. Po pričakovanju pa Slovenija dosega prednost pri cilju 3 \% povprečne letne rasti, saj kot ambiciozna nova članica mora dosegati visoke stopnje rasti, da se približa najrazvitejšim. So pa rezultati časovnih distanc bolj ugodni za Zahodno Slovenijo kot za Vzhodno. 


\section{Aleksander Aristovnik, Andrej Pungartnik \\ Uresničevanje ciljev Lizbonske strategije na regionalni ravni EU in Slovenija}

\section{Sklep}

Ob hitrem globalnem razvoju, tehnološkem napredku in gospodarskih ter okoljskih spremembah sta za doseganje gospodarske rasti vse pomembnejši razvojna dinamika in konkurenčnost. Voditelji vlad držav članic Evropske unije so zato v letu $2000 \mathrm{~s}$ sprejetjem Lizbonske strategije postavili okvirne cilje, ki naj bi jih EU dosegla $\vee$ desetih letih in tako postala najbolj konkurenčno, dinamično in na znanju temelječe gospodarstvo na svetu, ki bi bilo sposobno ustvarjati trajno gospodarsko rast, nova in boljša delovna mesta ter večjo socialno kohezijo. Z reformo v letu 2005 je Unija na novo definirala glavne cilje in prioritete, ob tem pa prepoznala kohezijsko politiko kot eno od glavnih politik Skupnosti za uresničitev strategije za rast in delovna mesta. Skladno z izvajanjem strategije na ravni Unije pa sledi izvajanju od vstopa v letu 2004, kot polnopravna članica EU, tudi Slovenija. Glede na to, da so razvojni izzivi, pred katerimi stoji, $v$ veliki meri podobni izzivom, pred katerimi se je znašla EU kot celota, je razumljivo, da so si tudi cilji zastavljeni $\vee$ strateških dokumentih Slovenije, kakor tudi EU, zelo podobni.

Koliko pa Slovenija ter Unija dejansko zaostajata za cilji, zapisanimi v Lizbonski strategiji, smo poizkušali pokazati z uporabo aplikacije Centra za socialne indikatorje, ki omogoča računanje časovnih distanc in odstopanj od ciljev. Zaradi pomanjkanja podatkov na regionalni ravni je sicer merjenje časovne distance za posamezne indikatorje onemogočeno oziroma oteženo. $V$ analizi so tako izračunane časovne distance za dva cilja Lizbonske strategije na ravni regij NUTS 2 in sicer cilja $70 \%$ stopnje zaposlenosti ter $3 \%$ povprečne letne rasti BDP do leta 2010.

Pri računanju časovnih distanc na ravni regij pridemo do ugotovitve, da tako pri sledenju cilja $70 \%$ stopnje zaposlenosti $\vee$ EU kot tudi cilja $3 \%$ povprečne letne rasti BDP EU najbolj in najmanj razvite regije, ki skupaj zajemajo $10 \%$ celotne populacije EU, zaostajajo za ciljnimi vrednostmi. Izjema so najmanj razvite regije na ravni EU-27, ki dosegajo prednost pri sledenju cilja povprečne letne stopnje rasti BDP, kar pa je pričakovano, saj morajo manj razvite regije rasti hitreje kot bolj razvite, da prihaja do konvergence in zmanjševanja razlik $v$ razvitosti. S tem časovna distanca tudi potrjuje rezultate iz dela o učinkih kohezijske politike na ravni regij, kjer je bila ugotovljena konvergenca med evropskimi regijami in zmanjšanje neskladij $v$ regionalni razvitosti. Na ravni Slovenije so rezultati pri sledenju ciljev sicer bolj ugodni, predvsem na področju zaposlenosti, pričakovano pa Slovenija dosega prednost pri cilju povprečne letne stopnje rasti BDP, kar velja za obe regiji na ravni NUTS 2. Je 


\section{Aleksander Aristovnik, Andrej Pungartnik \\ Uresničevanje ciljev Lizbonske strategije na regionalni ravni EU in Slovenija}

pa vendarle zaskrbljujoče dejstvo, da se razlike $v$ razvitosti med slovenskima regijama Vzhodna in Zahodna Slovenija ne zmanjšujejo, zato bodo $v$ prihodnje potrebna nadaljnja pospešena kohezijska vlaganja $\vee$ Vzhodno Slovenijo.

Rezultati računanja časovnih distanc tako $v$ grobem potrjujejo pričakovanja, da Unija kot tudi Slovenija na ravni regij NUTS 2 večinoma zaostajata za lizbonskimi cilji, z izjemo manj razvitih regij pri sledenju cilja povprečne letne stopnje rasti. Ugotovimo lahko, da bodo cilji Lizbonske strategije do leta 2010 zelo težko doseženi, saj je zaostanek predvsem na področju zaposlenosti prevelik, ob tem pa bodo dosego ciljev še dodatno otežile oziroma onemogočile globalna recesija ter $s$ tem upočasnjena gospodarska rast in povečanje brezposelnosti. A bojazen pred ekonomsko krizo ter posledično nedoseganje ciljev Unije je treba obrniti v še bolj odločno in konkretno uresničevanje strategije, saj lahko le na ta način omilimo učinke recesije.

Na ravni Unije je tako treba okrepiti akcijski načrt, ki bo uvedel kratkoročne ukrepe za omilitev krize ter priredil srednje in dolgoročne ukrepe Lizbonske strategije za boj proti recesiji. Stabilizirati je treba finančni trg, uvesti ukrepe za zmanjšanje tveganja ponovitve krize ter nadaljevati z izvajanjem strukturnih reform, predvsem na področjih, ki podpirajo inovacije in pospešujejo produktivnost ter delajo gospodarstva bolj fleksibilna in odporna. Ključno je torej, da se izvajanje strategije okrepi ob tem pa iz krize izstopi s še bolj učinkovito strategijo, ki bo pripravljena na izzive prihodnosti ter bo znala izrabiti priložnosti globalizacije.

Dr. Aleksander Aristovnik je diplomiral (1997), magistriral (2000) in doktoriral (2006) na Ekonomski fakulteti na Univerzi v Ljubljani. Konec leta 2001 se je zaposlil na Fakulteti za upravo na Katedri za ekonomiko in menedžment javnega sektorja. Leta 2006 je na Ekonomski fakulteti pridobil naziv docenta za področje mednarodne ekonomije, leta 2007 pa tudi naziv docenta za področje ekonomike javnega sektorja na Fakulteti za upravo. Raziskuje predvsem področja mednarodne ekonomije in financ, evropskih integracijskih procesov in javnih finance. Je član različnih mednarodnih združenj in organizacij. Rezultate svojega znanstvenega in raziskovalnega dela predstavlja na različnih domačih in tujih konferencah ter jih objavlja v vrsti strokovnih in znanstvenih revij.

Mag. Andrej Pungartnik je diplomiral in magistriral na Ekonomski fakulteti Univerze v Ljubljani s področja marketinga. Že med študijem je kazal veliko zanimanje za poglobljeno proučevanje regionalnega razvoja, teritorialnga sodelovanja in evropskih kohezijskih politik. Trenutno dela na področju oglaševanja. 


\section{Aleksander Aristovnik, Andrej Pungartnik Uresničevanje ciljev Lizbonske strategije na regionalni ravni EU in Slovenija}

\section{Literatura in viri}

- Aplikacija SICENTER. (2008). Http://www.gaptimer.eu/s-t-d_monitoring_tool.html (dostop 1.7.2009)

- $\quad$ Center za socialne indikatorje - SICENTER. (2008). Dostopno http://www.sicenter.si/indexsi.html (dostop 1.7.2009).

- Eurostat (2008). Dostopno na http://www.ec.europa.eu/eurostat/ (dostop 25.7.2009).

- Granger C.W.J., Jeon Y. (1997). Measuring Lag Structure in Forecasting Models - The Introduction of Time Distance. (San Diego: University of California).

- Granger C.W.J., Jeon Y. (2003). A time-distance criterion for evaluating forecasting models. International Journal of Forecasting, Vol. 19.

- Jones, A. R. (2001). The Politics and Economics of the European Union. (2nd ed.) (Northampton: Edward Elgar).

- Kok, W. (2004). Facing the challenge. The Lisbon strategy for growth and employment. (Luxembourg: Office for Official Publications of the European Communities).

- Martín, C. (2001). European Integration and Income Convergence, Lessons for Central and Eastern European Countries. (Washington: The World Bank).

- Müller, K. H. (2004). Time and Societal Evolution: The Theoretical background for Time Distance Analysis. (Vienna: WISDOM).

- Nacionalni strateški referenčni okvir 2007-2013. (2007). (Ljubljana: Služba Vlade RS za lokalno samoupravo in regionalno politiko).

- Nov začetek za Lizbonsko strategijo. (2005). (Luksemburg: Urad za uradne publikacije Evropskih skupnosti).

- $\quad$ NUTS. Klasifikacija statističnih teritorialnih enot v Evropski Uniji - NUTS pojasnilo. (2008). http://www.stat.si/tema_splosno_upravno_NUTS.asp (dostop 15.7.2009).

- Sicherl, P. (2003). Fleksibilnost dela - primerjalna analiza. (Ljubljana: Fakulteta za družbene vede).

- Sicherl, P. (2008). Monitoring implementation of Lisbon and NRP targets with S-timedistance measure. (Ljubljana: SICENTER).

- Služba vlade RS za evropske zadeve. (2008). Dostopno na http://www.svez.gov.si/si/aktualne_teme/lizbonska_strategija/ (dostop 23.7.2009)

- Time-distance analysis: method and applications. (2004). (Vienna: WISDOM). 